\title{
US courts and legislatures face implications of surrogacy
}

\section{Washington}

THE volatile issue of surrogate parents is once again bubbling. A test case in a New Jersey court will determine whether a contract requiring a surrogate mother to give up a child to the infant's genetic father and his wife is enforceable. Meanwhile, in New York state, a legislative committee is recommending drafting legislation setting up guidelines to regulate surrogacy, something no other state has yet done.

The New Jersey case arises from William and Elizabeth Stern's attempt to have a child through surrogacy because of Elizabeth Stern's medical condition, which makes child-bearing dangerous. Through the Infertility Center of New York, they contracted with Mary Beth Whitehead, a New Jersey housewife, for her to be artificially inseminated with William Stern's sperm. After being delivered of a baby girl, Mrs Whitehead initially gave her to the Sterns, but later decided she wanted to keep the baby. A court has given the Sterns temporary custody while deciding whether the contract between Mrs Whitehead and the Sterns can be enforced.

The New Jersey case embodies just one of the problems plaguing surrogacy. In the Stern-Whitehead case, both parties would like to keep the baby. But critics ask what would happen if the infant were deformed, when neither party might wish to keep it. Or what if the couple seeking the child simply changed their minds during the pregnancy?

US courts have already made some headway on the difficult issue of the rights of the genetic and the nurturing parents. There is a long-standing legal tradition that the woman who delivers the child is its mother. But H. Tristram Engelhardt, who deals with medical ethics at Baylor College of Medicine in Houston, emphasizes the distinction between a surrogate mother who provides the ovum and one who does not. Engelhardt says it is possible to consider the woman who 'lends' her uterus to nurture a fertilized egg as a temporary foster mother. According to Noel Keane, director of the Infertility Center of New York, a Michigan court has already recognized that the people providing the genetic material are a child's parents, regardless of who is actually delivered of the child.

But this genetic basis of determining parenthood has been challenged. Barbara Katz Rothman, a sociologist at Baruch College in New York, argues that the woman with the large belly and the swollen ankles is the mother, regardless of where the sperm and egg came from. She is concerned that, in the debate on surrogacy, the importance of a woman's nurtur- ing role during pregnancy is being overlooked.

Critics of surrogacy are also concerned about the commercial aspects of the procedure. They regard the payment of a fee to a surrogate parent as tantamount to selling babies. Infertile couples have been willing to pay large sums in order to have children. Typically, a surrogate mother will receive a $\$ 10,000$ fee; medical and legal costs and payments to intermediaries can put the total cost as high as $\$ 30,000$.

Angela Holder, professor of clinical paediatrics and law at Yale School of Medicine in New Haven believes surrogate arrangements worked out between close family members or friends, where no money changes hands, are justifiable.

The proposals issued earlier this month in New York, by the state legislature's Senate Judiciary Committee, would give legal sanction to surrogacy and also regulate costs. The committee's report stresses the importance of the informed consent of all parties through independent legal representation. The report urges that courts review all fees involved, using a standard of 'just and reasonable compensation' and that, after successful conception from artificial insemination with the intended father's semen, the surrogacy contract should be binding. The child would be deemed the legitimate natural child of the biological father and his wife. Legislation containing these recommendations will probably be introduced this month.

New York is not the first state to consider laws on surrogacy, but although five states have considered legislation, no laws have yet been adopted. In any case, legislation is unlikely to end the controversy. Lisa Newton, a philosopher at Fairfield University, believes legislation will simply create more difficulties. She believes that legal principles to deal with surrogacy do not exist, and that thoughtful legal decisions to provide precedents for future cases are now needed.

Many countries are wrestling with surrogacy issues. In Britain, the Warnock Report in 1985 urged that surrogacy for profit should be banned, and there is now legislation to that effect. In West Germany, a government commission is expected this week to set guidelines for surrogacy; last September, a conference of lawyers decided that surrogacy did not violate human dignity if the gestational mother provided her own ovum. In France, a presidential panel has been holding debates on the issue, and the Council of Europe has been hearing arguments on a set of provisional principles concerning human artificial procreation. Joseph Palca

\section{Official: UK's industry in a deep decline \\ London}

A MAJOR political row erupted last week with the publication of the latest employment statistics which showed that Britain's manufacturing industry is in deep decline and is continuing to shed jobs. The statistics, prepared by the Department of Employment and based on its 1984 Census of Employment, showed that the job losses were largely concentrated in the traditional manufacturing areas, mostly outside the affluent South-East.

Two million manufacturing jobs are estimated to have been lost since 1979 . with Scotland, Wales, Yorkshire, Humberside and the West Midlands bearing most of the burden.

The political criticisms were heaped on the government in the wake of the publication of the statistics that were hailed as proof that Britain has not properly invested in research and development and is increasingly becoming an assembly shop for foreign manufactured goods. Certainly the Cabinet Office, which is currently attempting to devise a new policy for British science, tailored by an influential secretariat, is highly critical of the amount of money available for development. The

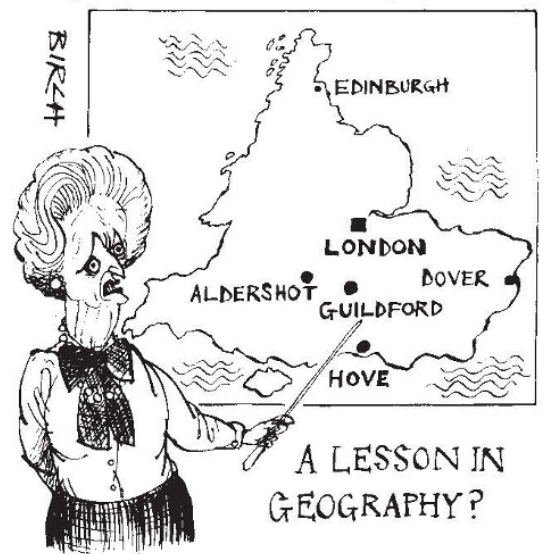

research monies are sufficient it claims, but that available to exploit science is inadequate.

The conclusions of the Department of Employment from the statistics indicate that there will be little relief in the manufacturing sector in the immediate future. The latest figures on employment in manufacturing, says the department, show a decrease of 10,000 per month in the three months ending October. Although estimates have fluctuated from month to month, the average rate of decrease so far this year has been 14,000 per month. These revised estimates, the officials claim, "show a greater decrease in manufacturing employment than was previously thought",
Bill Johnstone 